\title{
The role of supervision of school principal as an effort to improve teacher professionalism in teaching
}

\author{
Herlinawati Herlinawati $^{1}$, Muhammad Kristiawan ${ }^{2}$, Alforqi Alforqi ${ }^{3}$ \\ ${ }^{1}$ Sekolah Menengah Atas Negeri 10 OKU, Indonesia \\ ${ }^{2}$ Universitas Bengkulu, Indonesia \\ ${ }^{3}$ Universitas PGRI Palembang, Indonesia
}

\section{Article Info \\ Article history: \\ Received Jul $8^{\text {th }}, 2021$ \\ Revised Aug 12 ${ }^{\text {th }}, 2021$ \\ Accepted Aug $30^{\text {th }}, 2021$ \\ Keyword: \\ Supervision \\ Principal \\ Teacher professionalism}

\begin{abstract}
The principal is a leader in educational institutions that regulates and manages educational activities in schools. Therefore, school principals play an important role in improving the quality of education, especially improving teacher performance to be more enthusiastic and professional in teaching and developing themselves who are in charge of delivering lessons to students. This study aims to identify the role of principal supervision as an effort to improve teacher professionalism in teaching at public high school (SMA Negeri) 10 OKU. This research was conducted at SMA Negeri 10 OKU. The research was carried out for 3 (three) months, starting from September 2020 to November 2020. The research method used was a qualitative descriptive method. Data collection techniques used include: (1) Interview or Interview; (2) Observation; (3) Documentation. Based on the research results, it was concluded that the principal had a role in the supervision carried out as an effort to improve teacher professionalism in teaching. It is known: (1) The role of principal supervision is evidenced by the teacher in planning lesson plans which are made reported and approved by the principal and according to the curriculum; (2) The role of principal supervision is proven by the teacher in carrying out the learning process in accordance with the learning device guidelines and using teaching aids; (3) The role of principal supervision is evidenced by the teacher evaluating the learning outcomes and reporting to the principal; (4) The role of principal supervision is evidenced by the teacher following up on the learning outcomes in accordance with the direction of the principal; (5) The role of principal supervision is evidenced by the teacher providing guidance to students.
\end{abstract}

(C) 2021 The Authors. Published by IICET.

This is an open access article under the CC BY-NC-SA license

(https://creativecommons.org/licenses/by-nc-sa/4.0

\section{Corresponding Author:}

Herlinawati, H.,

Sekolah Menengah Atas Negeri 10 OKU, Indonesia

Email: herlinawatibaturaja@gmail.com

\section{Introduction}

The future of a nation should be guaranteed. If not, it will cause serious threats to the survival of a nation. Schools are official educational institutions that carry out teaching and learning activities as an effort to achieve educational goals. The level of education quality is influenced by the quality of the learning process carried out by the teacher, because the teacher directly provides subject matter directly to students [1]. 
Besides that, every institution or educational institution has a leader. The principal is a leader in educational institutions that regulates and manages educational activities in schools. Therefore, currently school principals play an important role in improving the quality of education, especially improving teacher performance to be more enthusiastic and professional in teaching and developing themselves in charge of delivering lessons to their students.

This shows that teachers are expected to be able to play an active role as managers of the teaching and learning process, act as facilitators who always try to create class organizations, use teaching methods and teacher attitudes and characteristics in managing the teaching and learning process [2]. Furthermore, Yuliati [3] explains that the principal as a supervisor has the responsibility for increasing the ability of teachers to manage learning activities in schools and has a very important role in the development and progress of a school.

Based on this, the principal must supervise properly and correctly in accordance with the principles and techniques as well as the right approach. Coaching carried out by the principal to the teacher can improve teacher performance and dedication in education. Supervision is carried out by the principal, namely to improve the competence of teachers in teaching and learning activities, so that they are expected to fulfill the teaching mission they carry or the national education mission in a wider scope. As is well known, the problem of the teaching profession in carrying out teaching and learning activities will always and continue with supervision assistance from the principal [4]

Furthermore, Burhanuddin [4] argues that the purpose of supervision is to develop a better teaching and learning situation through fostering and improving the teaching profession, in detail as follows: (1) Increasing the efficiency and effectiveness of teaching and learning; (2) Controlling the implementation of technical educational fields in schools in accordance with the stipulated provisions and policies; (3) Ensuring that teaching and learning activities take place in accordance with applicable regulations, so that they run smoothly and obtain optimal results; (4) Assessing the success of the school in carrying out its duties; and (5) Providing direct guidance to fix problems, shortcomings and mistakes and help solve problems faced by schools so that further errors can be prevented.

Zahroh [5] states that teachers have great potential in themselves, but this potential has not been stated in full teaching activities because they have not received stimulation and motivation from supervisors as school leaders and their seniors. Principal supervision is the principal's ability to influence teachers as subordinates to be able to work together to carry out their work activities in order to improve performance by providing motivation and awareness so that teachers work fully according to their capacity. Principals are required to be able to cooperate with subordinates, in this case, of course, are teachers.

From the results of the preliminary observations that have been made, the researcher found several problems in the implementation of the principal's duties including: (1) The lack of the supervisory role of the principal given to empower school resources, especially teachers in achieving educational goals; (2) Lack of infrastructure as a support for improving the quality of education at SMA Negeri $10 \mathrm{OKU}$, so that the impact on teachers in delivering learning material is not optimal; (3) Lack of teacher professionalism in class management. Therefore, this research was carried out aimed at identifying the role of principal supervision as an effort to improve teacher teaching techniques in teaching at SMA Negeri 10 OKU.

\section{Method}

This research was conducted at SMA Negeri 10 OKU. The research period was carried out for 3 (three) months, starting from September 2020 to November 2020. Research Methods Zuldafrial [6] argues that the data source is the subject from which data can be obtained. Furthermore, Sugiyono [7] explains that when viewed from the data source, data collection can use primary and secondary sources. Primary data sources are data sources that directly provide data to data collectors, and secondary sources are sources that do not directly provide data to data collectors.

Based on the theoretical explanation above, the primary data sources obtained from this study were 37 teachers in SMA Negeri 10 OKU consisting of 13 PNS teachers and 24 honorary teachers. While the secondary data source is in the form of interviews aimed at school principals and teachers related to the professionalism of teachers in teaching. Arikunto [8] states that in a study data is needed. In data collection, techniques are needed, both techniques in providing data, and techniques in classifying the data that has been collected. The data collection method is a method used to collect data, while the data collection technique is the method used in carrying out the method that has been chosen. In short, it can be said that a method is a method, whereas a technique is a way to carry out a method that has been chosen. This research is a field 
study, so the desired data can only be obtained from the field, the research location. Data collection techniques in this study include the following $[9,10,11]$ :

According to Arikunto [8], interviews or interviews are data in which research is face to face with respondents in order to obtain the required data or information. The interview method is a method that is very effective in qualitative research. The interview used in this research is a structured interview, which is to ask written questions first as a guide but the element of freedom is still maintained, so that reasonableness can still be maximally achieved to obtain in-depth data. According to Arikunto [8], observation is defined as systematic observation and recording of the symptoms that appear on the research object. Observations and records are made of the symptoms that appear on the object where the event occurs or the process in each school.

Documentation is a data event is taking place, so that the observer is with the object being investigated, which is called observational observation that the researcher will carry out is direct observation of the occurrence of events, namely how the school-based management process and teacher professionalism and teacher performance in the learning collection technique in order to obtain written facts, namely in the form of documents, reports, archives and / or other written materials related to the focus of research [8]. The documentation used as data collection material in this study is in the form of interview guidelines and interview results sheets, research permits, school profiles which include learning resources and other supporting documents in order to complement the research data.

The data analysis techniques in this study were analyzed qualitatively and quantitatively. [7] states that qualitative data analysis is a continuous, repetitive and continuous effort. According to [7], there are three stages of qualitative data analysis, namely: data reduction, display or presentation of data as well as drawing conclusions and data verification. Meanwhile, quantitative data analysis uses a formula to input the scores from the research results [8].

\section{Results and Discussions}

SMA Negeri 10 OKU which was used as the research location is located on Jalan Raya Baturaja-Muaradua, Tanjung Lengkayap Village, Lengkiti District, Ogan Komering Ulu Regency. In the learning process at SMA Negeri 10 OKU held at $07.30 \mathrm{WIB}$ to $14.15 \mathrm{WIB}$, while extracurricular activities were carried out on Saturdays which were held at 14.00 WIB until 15.30 WIB.

Based on the research observation findings data, the following data were obtained:

1) Principal's Office $\square$ Good

2) Teacher's Room $\square$ Good

3) Study Room $\square$ Good

4) Student desks $\square$ Good

5) Student seats $\square$ Good

6) UKS Room $\square$ Good

7) Library Room $\square$ Good

8) Chemical Laboratory $\square$ Good

9) Biology Laboratory $\square$ Good

10) Physics Laboratory $\square$ Enough

11) Computer Laboratory $\square$ Good

12) Mushollah Room $\square$ Good

13) School Canteen $\square$ Good

14) Sports Equipment $\square$ Something was broken

15) Art Tools $\square$ Something's broken

16) School Field $\square$ Good

Teacher Observation Results:

1) The teacher plans the lesson plan

2) The teacher makes lesson plans

3) Teachers in implementing learning.

4) Teachers in evaluating learning outcomes

5) Teachers in providing guidance to students

6) Teachers in improving the quality of education

At SMA Negeri 10 OKU in learning activities assisted by 34 teachers consisting of 13 civil servant teachers and 21 honorary teachers, with a total of 401 students and 12 study groups consisting of 4 (four) study groups 
class X (ten), 4 (four) class XI (eleven) study groups, and 4 (four) class XII (twelve) study groups. Regarding the professionalism of teachers in teaching, the best graduation rate in SMA Negeri 10 OKU in 2017/2018 the highest score was 5.60 in 2018/2019 the highest student passing score was 5.55 and while for the 2019 learning year / 2020 UNBK, whose name changed to USP (Education Unit Examination) could not be implemented due to the COVID-19 outbreak, an epidemic that has hit the whole world in general and in particular Indonesia which did not allow the implementation of the USP.

\section{Conclusions}

Based on the research findings, it is known that the principal has played a role in the supervision carried out as an effort to improve teacher professionalism in teaching. The supervisory role of the principal is evidenced by the teacher in planning the lesson plans which are made reported and approved by the principal and according to the curriculum. The teacher was carrying out the learning process according to the learning device guidelines and using props. Teachers in delivering learning have used other sources from books with various publishers besides handbooks. In the learning process the teacher has done learning activities outside the classroom, this is done so that the learning process is not boring. When the teacher delivers the learning material using teaching aids, the students better understand the material presented. Because the teaching aids used can be motivate students to learn. The teacher provides guidance to students who have difficulty learning. The teacher gives directions to students to always carry handbooks when participating in the learning process. Teachers often provide guidance and counselling when there are students who commit disturbances by giving advice and directing these students not to repeat their actions [12].

Based on the description above, the researcher provides input in the form of suggestions to the following parties.

1. The principal, in providing supervision, should be carried out on a schedule so that evaluation can be carried out and existing deficiencies can be overcome, so that the quality of education can be even better.

2. Teachers should always improve professionalism in teaching, either by adding insight, improving teaching techniques so that students are able to absorb any material presented.

3. The Education Office should always provide direction and guidance for schools in Ogan Komering Ulu Regency, especially in SMA Negeri $10 \mathrm{OKU}$ so that the quality of education can be improved.

\section{References}

Ekosusilo. (2013). Supervisi Pendidikan. Jakarta: Raja Graffindo Persada.

Suharsaputra. (2018). Supervisi Pendidikan (Pendekatan Sistem Berbasis Kinerja). Bandung: Refika Aditama.

Yuliati, E.A. (2018). Kepemimpinan Transformasional Kepala Sekolah. Salatiga: Griya Media.

Burhanuddin. (2015). Belajar dan Pembelajaran. Bandung: Alfabeta.

Zahroh, A. (2015). Membangun Kualitas Pembelajaran Melalui Dimensi Profesionalisme Guru. Bandung: Yrama Widya.

Zuldafrial, A. (2012). Metode Penelitian. Jakarta: Dian Pustaka.

Sugiyono. (2015). Metode Penelitian Pendidikan, Pendekatan Kuantitatif, Kualitatif dan R \& D. Bandung: Alfabeta.

Arikunto, S. (2010). Prosedur Penelitian Suatu Pendekatan Praktek. Edisi Revisi. Jakarta: Rineka Cipta.

Morgan, G. A., \& Harmon, R. J. (2001). Data collection techniques. Journal american academy of child and adolescent psychiatry, 40(8), 973-976.

Allen-Meares, P., \& Lane, B. A. (1990). Social work practice: Integrating qualitative and quantitative data collection techniques. Social Work, 35(5), 452-458.

Barker, K. N. (1980). Data collection techniques: observation. American Journal of Hospital Pharmacy, 37(9), 1235-1245.

Zhou, J. (2012). The effects of reciprocal imitation on teacher-student relationships and student learning outcomes. Mind, Brain, and Education, 6(2), 66-73.. 